\title{
Interventions and strategy to mitigate HIV related risk behavior among young men in India
}

\author{
Vipul Vipul ${ }^{*}$, Srikant Srikant \\ From $16^{\text {th }}$ International Symposium on HIV and Emerging Infectious Diseases \\ Marseille, France. 24-26 March 2010
}

\section{Background}

Adolescents present both a challenge as well as an opportunity while exploring the linkages between HIV related risk behaviour across different sub populations. Adolescents are an unprecedented large and growing population, especially in developing world like INDIA. With sexual activity often initiated in adolescence -within or outside of marriage - the risk relating to their sexual behaviour is often underestimated.

Therefore, this paper focuses at the extent of comprehensive knowledge among young men age 15-24 and the socio-economic and contextual correlates of HIV related risk behaviors in India, which may have top programmatic priorities for designing evidence based interventions.

\section{Methods}

The basic data used in this paper has been taken from the third round of National Family Health Survey (NFHS-3), where it is the first time when information on HIV related risk behavior have been collected from a nationally representative sample of men age 15-54 and women age 15-49 irrespective of their marital status. Bivariate, multivariate and logistic modeling statistical techniques are used for the analysis.

\section{Results}

Only one-third (36 percent) of the young men in India have "comprehensive knowledge" about HIV/AIDS- a pre requisite for effectiveness in prevention and control programme in any country. Overall 6 percent of the young men reported to have an "intention to have sex before marriage" and the study clearly reveals that among the youth who are consuming alcohol and who have frequent mobility are more likely to have an

\footnotetext{
* Correspondence: vipulvaibhav.pandey@gmail.com
} IIPS, Mumbai, India intention for the pre marital sex. Data depict that, though 15 percent of the youth reported to be used condom during their first sexual intercourse, only 7 percent of the never married men reported to use condom shows that the involvement in safe sexual practices among the young men. Overall nearly 4 percent of youth in India are involved in risky sexual behavior.

\section{Discussion}

Thus the need to focus on young men and their involvement in the existing HIV/AIDS intervention programs is essential. Intervention programs should focus at enhancing not only the "comprehensive knowledge" but also "condom promotion" and "safer sexual practices". While deciding the research priorities and also designing programmatic response to the epidemic.

Published: 11 May 2010

doi:10.1186/1742-4690-7-S1-P145

Cite this article as: Vipul and Srikant: Interventions and strategy to mitigate HIV related risk behavior among young men in India. Retrovirology 2010 7(Suppl 1):P145.
Submit your next manuscript to BioMed Central and take full advantage of:

- Convenient online submission

- Thorough peer review

- No space constraints or color figure charges

- Immediate publication on acceptance

- Inclusion in PubMed, CAS, Scopus and Google Scholar

- Research which is freely available for redistribution

Submit your manuscript at www.biomedcentral.com/submit
C Biomed Central 